\title{
ANALISIS KETERPADUAN PASAR ANTARA PEDAGANG BESAR TAN PEDAGANG KECIL KOMODITAS CABAI RAWIT PADA PASAR RAKYAT DI KABUPATEN SITUBONDO( STUDI KASUS DI PASAR PANJI KABUPATEN SITUBONDO)
}

\author{
Mohammad Fadli \\ Prodi Agribisnis, Fakultas Pertanian, Universitas Abdurachman Saleh, Situbondo \\ *Email Korespondensi : mf12071997@gmail.com
}

\begin{abstract}
Abstrak
Penelitian ini bertujuan untuk mengetahui tingkat keterpaduan pasar dalam jangka pendek antara pedagang besar dan pedagang kecil komoditas cabai rawit di pasar Panji Kabupaten Situbondo dan untuk mengetahui sikap pedagang besar dan pedagang kecil terhadap harga cabai rawit pada bulan dasar dan bulan sebelumnya. Data yang digunakan terdiri dari data primer dan data sekunder. Metode pengolahan dan analisis data yang digunakan adalah analisis deskriptif, Autoregressive distributed lag, Analisis skala likert, IMC. Hasil penelitian menunjukkan : 1). Tingkat keterpaduan pasar antara pedagang kecil dengan pedagang besar memiliki keterpaduan pasar yang rendah dengan nilai IMC 1,33. Nilai IMC tinggi apabila harga cabai rawit pada pedagang kecil tinggi dan harga cabai rawit di pedagang besar rendah. Nilai IMC rendah apabila harga cabai rawit pada pedagang kecil rendah dan di pedagang besar tinggi. 2). Sikap pedagang besar dan pedagang kecil terhadap harga cabai rawit pada bulan dasar dan bulan sebelumnya rendah. Tingkat keterpaduan pasar antara pedagang kecil dengan pedagang besar memiliki keterpaduan pasar yang rendah dan sikap pedagang besar dan pedagang kecil terhadap harga cabai rawit pada bulan dasar dan bulan sebelumnya rendah.
\end{abstract}

Kata kunci: Keterpaduan pasar, Cabai rawit, Pedagang Besar, Pedagang Kecil

Abstract
This study aims to determine the level of market cohesiveness in the short term between wholesalers and small traders of cayenne chili commodities inPanjitraditional market in Situbondo Regency and to determine the attitudes of wholesalers and small traders through the price of cayenne pepper in the base month and the previous month. The data used consists of primary data and secondary data. Data processing and analysis methods used are descriptive analysis, Autoregressive distributed lag, Likert scale analysis, IMC. The results showed: 1). The level of market cohesivenessbetween small traders and wholesalers have low cohesiveness with an IMC percentage of 1.33. IMC percentage considered high if onlythe price of cayenne chili at small traders is higher than wholesalers' cayenne chile. IMC percentage considered low if only the price of cayenne chili at small traders is lower than wholesalers' price. 2). The attitude of wholesalers and small traders through the price of cayenne chili in the base month and the previous month was low. The level of market cohesiveness between small traders and wholesalerswas low and the attitude of wholesalers and small traders through the price of cayenne chili in the base month and the previous month is low.

Keywords: Market cohesiveness, cayenne chile, wholesalers, Small Traders

\section{PENDAHULUAN}

Di Provinsi Jawa Timur, cabai merupakan komoditas yang cukup potensial untuk dikembangkan terutama di Kabupaten Situbondo yang merupakan podusen cabai terbesar ke sepuluh di Jawa Timur. Kabupaten Situbondo merupakan salah satu daerah produksi cabai cukup tinggi yaitu 152. 485 ton. Walaupun Situbondo 
merupakan salah satu daerah produksi cukup tinggi, namun dalam kegiatan usahatani masih mengalami berbagai kendala terutama dalam pemasaran. Cabai sering mengalami fluktuasi harga yang relatif tajam, salah satunya cabai rawit. Kabupaten Situbondo sebagai salah satu daerah penghasil cabai rawit, membutuhkan pasar untuk memasarkan produknya, baik pasar di dalam maupun pasar di luar Kabupaten Situbondo. Pemasaran produk di dalam Kabupaten Situbondo terkait dengan produksi cabai rawit pada setiap kecamatan yang berbeda-beda. Sebagian kecamatan menghasilkan cabai rawit dengan produksi yang tinggi, sebagian lagi ada kecamatan yang memproduksi cabai rawit rendah. Berikut ini merupakan data produksi cabai rawit di Kabupaten Situbondo:

Tabel 1. Luas Panen dan Produksi Cabai Rawit Setiap Kecamatan di Kabupaten Situbondo Tahun

\begin{tabular}{|c|c|c|}
\hline & 2017 & \\
\hline Kecamatan & Luas panen $(\mathrm{Ha})$ & Produksi (kw) \\
\hline 1. Sumbermalang & 24,0 & 3.380 \\
\hline 2. Jatibanteng & 21,0 & 5.590 \\
\hline 3. Banyuglugur & 61,0 & 28.090 \\
\hline 4. Besuki & 5,0 & 3.360 \\
\hline 5. Suboh & 109,0 & 45.190 \\
\hline 6. Mlandingan & 34,0 & 7.690 \\
\hline 7. Bungatan & 223,0 & 151.360 \\
\hline 8. Kendit & 30,0 & 14.550 \\
\hline 9. Penarukan & 13,0 & 4.850 \\
\hline 10. Situbondo & 1,0 & 200 \\
\hline 11. Mangaran & 72,0 & 2.160 \\
\hline 12. Panji & 18,0 & 2.860 \\
\hline 13. Kapongan & 15,0 & 1.890 \\
\hline 14. Arjasa & 215,0 & 214.600 \\
\hline 15. Jangkar & 122,0 & 46.000 \\
\hline 16.Asembagus & 122,0 & 6.680 \\
\hline 17. Banyuputih & 603,0 & 424.490 \\
\hline
\end{tabular}

\begin{tabular}{ccc}
\hline Situbondo & $\mathbf{1 . 5 6 6 , 0}$ & $\mathbf{9 6 2 . 9 4 0}$ \\
\hline \hline Sumber: (Dinas Tanaman Pangan, Holtikultura, dan Perkebunan Kabupaten Situbondo 2017, n.d.)
\end{tabular}

Berdasarkan Tabel 1.3 dapat dilihat bahwa semua kecamatan memproduksi cabai rawit. Kecamatan yang memliki lahan panen cabai rawit tertinggi adalah Kecamatan Banyuputih dan yang terendah adalah Kecamatan Situbondo. Situbondo sebagai pusat kota tentunya akan mendatangkan cabai dari kecamatan lain. Kabupaten Situbondo merupakan salah satu produsen tertinggi cabai rawit di Jawa Timur. Di sisi lain tidak semua daerah atau kecamatan di Kabupaten Situbondo mampu memproduksi cabai rawit dengan maksimal sehingga harus mendatangkan komoditas tersebut dari kecamatan atau daerah lain yang mampu memproduksi. Pemasaran cabai rawit di Situbondo disalurkan ke pasar pasar

Penelitian ini bertujuan untuk mengetahui tingkat keterpaduan pasar dalam jangka pendek antara pedagang besar dan pedagang besar komoditas cabai rawit dan sikap pedagang besar dan pedagang kecil terhadap harga cabai rawit pada bulan dasar dan bulan sebelumnya di Pasar Panji Kabupaten Situbondo. Simatupang dan Sitomorang (2016) menjelaskan bahwa keterpaduan pasar ialah 
hubungan yang saling mempengaruhi dalam hal perubahan harga antara dua pasar. Dewasa ini produsen tidak langsung menjual kepada konsumen akhir namun melalui beberapa saluran. Biasanya pemain pemainnya mengambil untung yang cukup besar. Pedagang besar dan pedagang kecil juga memiliki andil cukup besar didalamnya. Hal tersebut yang membuat peneliti tertarik untuk meneliti bagaimana tingkat keterpaduan pasar jangka pendek antara pedagang besar dan pedagang kecil komoditas cabai rawit dan sikap pedagang besar dan pedagang kecil terhadap harga cabai rawit pada bulan dasar dan bulan sebelumnya di Pasar Panji Kabupaten Situbondo(Simatupang, 2016).

\section{METODE PENELITIAN}

Penelitian ini dilakukan di Pasar Panji Kecamatan Panji Kabupaten Situbondo dengan obyek penelitian pedagang besar dan pedagang kecil komoditas cabai rawit. Sampel pedagang besar dengan cara aksidental sampling dan pedagang kecil sebanyak 30 responden. Pengumpulan data dengan wawancara dan pencatatan. Data bersumber dari data perimer dan sekunder. Data yang terkumpul kemudian dianalisis menggunakan Autoregressive Distributed Lag, IMC, dan skala likert. Alatalat penguji yang digunakan antara lain Uji $\mathrm{R}^{2}$, uji F, uji t.

\section{HASIL DAN PEMBAHASAN}

1. Respon Pedagang Besar dan Pedagang Kecil Terhadap Harga Cabai Rawit Bulan Dasar dan Bulan Sebelumnya

a. Pedagang Besar

Berdasarkan kuisioner yang disebar kepada pedagang besar diketahui jawaban dari responden sebagai berikut.

Tabel 3. Tanggapan responden terhadap harga cabai rawit bulan dasar dan bulan sebelumnya

\begin{tabular}{|c|c|c|}
\hline Variabel & Rata Rata & Kategori \\
\hline $\begin{array}{l}\text { Harga cabai rawit di } \\
\text { pedagang kecil pada bulan } \\
\text { sebelumnya }\end{array}$ & 3,06 & Sedang \\
\hline $\begin{array}{l}\text { Selisih harga cabai rawit di } \\
\text { pedagang besar bulan dasar } \\
\text { dan bulan sebelumnya }\end{array}$ & 2,73 & Rendah \\
\hline $\begin{array}{l}\text { Harga cabai rawit di } \\
\text { pedagang besar pada bulan } \\
\text { tertentu }\end{array}$ & 3,20 & Sedang \\
\hline
\end{tabular}

Sumber: Data primer yang diolah 2020

Berdasarkan data yang diperoleh dari kuisioner yang dikembalikan oleh pedagang besar, secara keseluruhan rata rata varabel sedang. Variabel Harga cabai rawit di pedagang kecil pada bulan sebelumnya sedang yang menggambarkan tingkat kepedulian pedagang besar rendah terhadap harga cabai rawit di pedagang kecil pada bulan sebelumnya. Sementara variabel selisih harga cabai rawit di pedagang besar bulan dasar dan bulan sebelumnya sedang. Hal ini menggambarkan bahwa pedagang besar kurang memperhatikan selisih harga cabai rawit di pedagang besar bulan dasar dan bulan sebelumnya. Untuk variabel Harga cabai rawit di pedagang besar pada bulan tertentu sedang, hal ini memperlihatkan bahwa tingkat kepedulian pedagang besar terhadap variabel 
harga cabai rawit di pedagang besar pada bulan tertentu rendah. Tingakt kepedulian yang rendah mampu membuat kondisi pasar tidak stabil yang bisa menyebabkan keterpaduan pasar rendah karenda informasi harga yang tidak tersalurkan dengan baik. Dan tingkat kepedulian yang tinggi menggambarkan keterpaduan pasar tinggi. Semakinpeduli pedagang besar dan pedagang kecil terhadap peubahan harga bulan dasar dan bulan sebelumnya makan akan semakin besar kemungkinan tingkat keterpaduan pada pasar tersebut tingi.

\section{b. Pedagang Kecil}

Berdasarkan kuisioner yang disebar kepada pedagang besar diketahui jawaban dari responden sebagai berikut.

Tabel 4. Tanggapan responden terhadap harga cabai rawit bulan dasar dan bulan sebelumnya

\begin{tabular}{lcc}
\hline \hline \multicolumn{1}{c}{ Variabel } & Rata Rata & Kategori \\
\hline $\begin{array}{l}\text { Harga cabai rawit di } \\
\text { pedagang kecil pada bulan } \\
\text { sebelumnya }\end{array}$ & 2,97 & Rendah \\
$\begin{array}{l}\text { Selisih harga cabai rawit di } \\
\text { pedagang besar bulan dasar } \\
\text { dan bulan sebelumnya }\end{array}$ & 2,98 & Rendah \\
$\begin{array}{l}\text { Harga cabai rawit di } \\
\text { pedagang besar pada bulan } \\
\text { tertentu }\end{array}$ & 4,12 & Tinggi \\
\hline \hline
\end{tabular}

Berdasarkan data yang diperoleh dari kuisioner yang dikembalikan oleh pedagang keci bervariasi.. Variabel harga cabai rawit di pedagang kecil pada bulan sebelumnya rendah yang menggambarkan pedagang kecil tidak memperhatikan terhadap harga cabai rawit di pedagang kecil pada bulan sebelumnya. Sementara variabel selisih harga cabai rawit di pedagang besar bulan dasar dan bulan sebelumnya rendah. Hal ini menggambarkan bahwa pedagang kecil tidak memperhatikan selisih harga cabai rawit di pedagang besar bulan dasar dan bulan sebelumnya. Untuk variabel harga cabai rawit di pedagang besar pada bulan tertentu tinggi, hal ini memperlihatkan bahwa pedagang kecil memperhatikan harga cabai rawit di pedagang besar pada bulan tertentu. Tingakt kepedulian yang rendah mampu membuat kondisi pasar tidak stabil yang bisa menyebabkan keterpaduan pasar rendah karenda informasi harga yang tidak tersalurkan dengan baik. Dan tingkat kepedulian yang tinggi menggambarkan keterpaduan pasar tinggi. Semakinpeduli pedagang besar dan pedagang kecil terhadap peubahan harga bulan dasar dan bulan sebelumnya makan akan semakin besar kemungkinan tingkat keterpaduan pada pasar tersebut tingi.

\section{c. Perkembangan Harga Cabai Rawit Pedagang Besar dan Pedagang Kecil}

Untuk mengetahui lebih jelas mengenai perkembangan harga cabai rawit, dapat diketahui dengan data dari dua pedagang yang diteliti tersebut yaitu pedagang besar dan pedagang kecil, kemudian dapat digambarkan .grafik perubahan harga pada dua jenis pedagang tersebut. Selain itu dengan digambarkan grafiknya, maka akan terlihat dengan jelas fluktuasi harga yang terjadi dan perbedaannya bisa lebih jelas. Berikut ini adalah gambar grafik 
perubahan harga cabai rawit selama 12 bulan pedagang besar dan pedagang kecil dari Bulan Januari 2019-Desember 2019.

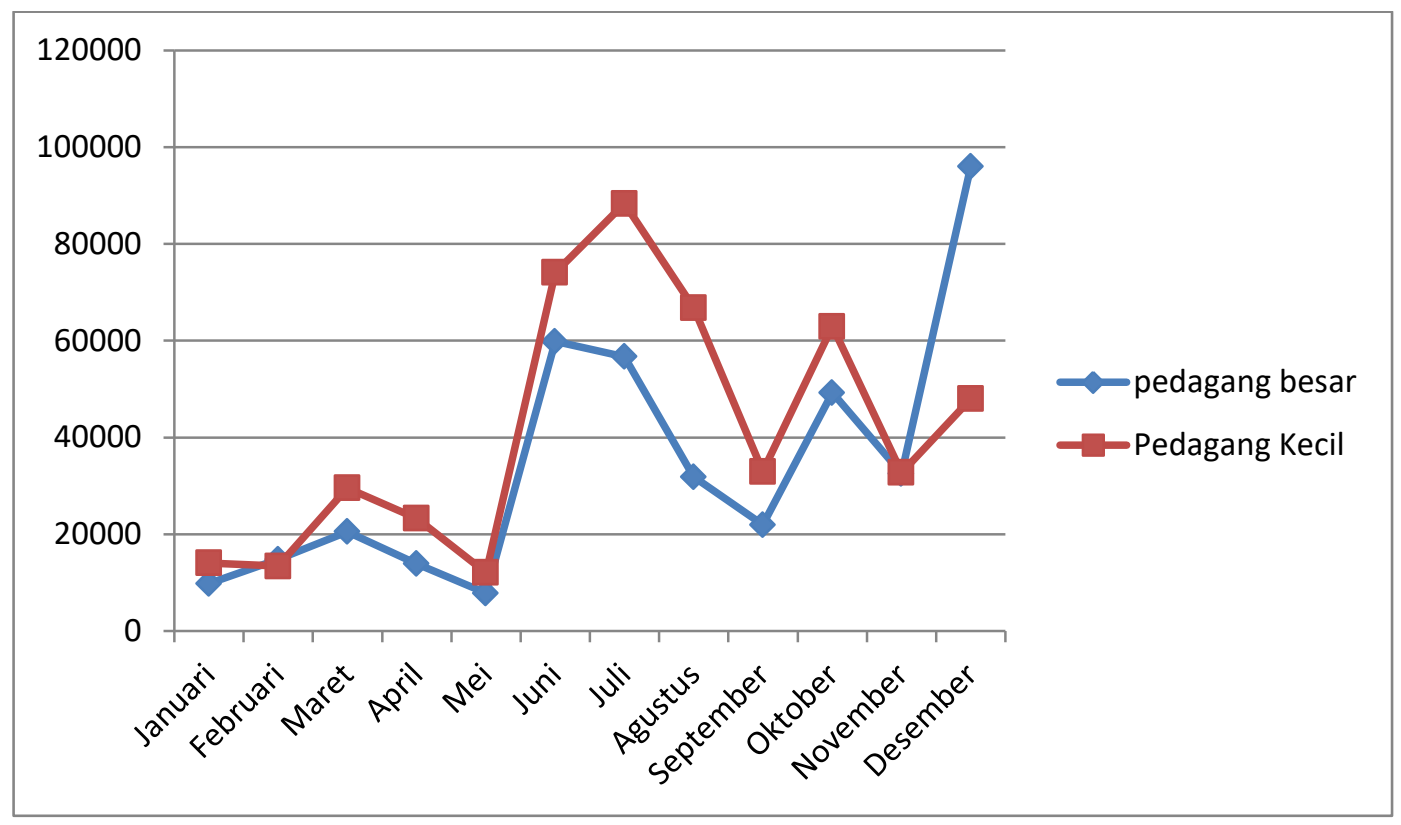

Gambar 1. Grafik Harga Riil Cabai Rawit di Pedagang Besar dan Pedagang Kecil di Pasar Panji Januari 2019-Desember 2019

Berdasarkan gambar 1 tersebut dengan jelas diketahui bahwa hampir secara keseluruhan harga cabai rawit di pedagang besar selalu lebih rendah dibanding dengan pedagang kecil. Akan tetapi tidak sepenuhnya demikian. Hal tersebut terjadi pada bulan Februari dan Desember 2019, dimana harga cabai rawit di pedagang besar justru memiliki harga tertinggi dibanding pedagang kecil yaitu pada bulan Februari Rp 14.821,62/Kg dan Desember Rp 96.000/Kg. Sedangkan secara keseluruhan selama bulan Januari sampai Bulan Desember 2019 harga cabai rawit tertinggi terjadi di pedagang besar pada bulan Desember $2019 \mathrm{Rp}$ 96.000 dan harga terendah di pedagang besar pada bulan Desember $2019 \mathrm{Rp}$ $7.834,91 / \mathrm{Kg}$.

Jarak antara pedagang besar dan pedagang jecil sangta mempengaruhi tingat keterpaduan pasar, karena hal tersebut berkaitan dengan informasi harga yang disalurkan. Informasi harga yang kurang cepat dan tergolong lammbat akan membuat jarak perubahan harga pedagang besar dan pedagang kecil jauh yang mengakibatkan keterpaduan pasar rendah.

\section{d. Analisisi Keterpaduan Pasar Cabai Rawit antara Pedagang besar dengan Pedagang Kecil di Pasar Panji \\ Hasil analisis regresi antara dua pedagang didapatkan angka-angka yang dapat digunakan untuk merumuskan suatu permasalahan ekonomi dengan pendekatan ekonometrika. Berikut hasil analisis regresi:}


Tabel 5. Hasil analisis regresi model keterpaduan pasar

\begin{tabular}{|c|c|c|c|c|c|c|c|c|}
\hline $\begin{array}{l}\text { Variabel } \\
\text { Independ } \\
\text { ent }\end{array}$ & $\begin{array}{c}\text { Koefesien } \\
\text { Regresi }\end{array}$ & $\begin{array}{c}\mathrm{t} \\
\text { hitung }\end{array}$ & $\begin{array}{c}\mathrm{t} \\
\text { tabel }\end{array}$ & $\begin{array}{l}\text { Proba } \\
\text { bilitas }\end{array}$ & $\begin{array}{c}\mathrm{F} \\
\text { hitung }\end{array}$ & $\begin{array}{c}\mathrm{F} \\
\text { tabel }\end{array}$ & $\begin{array}{l}\text { Proba } \\
\text { bilitas }\end{array}$ & $\mathrm{R}^{2}$ \\
\hline P1t-1 & $0,658^{\text {ns }}$ & 9,808 & 1,79 & 0,000 & 179,663 & 4,96 & 0,000 & 0,98 \\
\hline PAt-PAt-1 & $0,18^{*}$ & 0,343 & & 0,741 & & & & \\
\hline PAt-1 & $0,494^{*}$ & 8,585 & & 0,000 & & & & \\
\hline
\end{tabular}

\section{Pembahasan}

\section{a. Koefisien Determinasi ( $\mathbf{R}^{\mathbf{2}}$ )}

Uji $\mathrm{R}^{2}$ digunakan untuk mengetahui kesesuaian model yang digunakan. Nilai $\mathrm{R}^{2}$ untuk mengetahui pengaruh variabel bebas dalam menerangkan variabel tidak bebasnya. Hasil analisis regresi antara pedagang besar dan pedagang kecil didapat nilai koefisien determinasinya $\left(\mathrm{R}^{2}\right)$ sebesar 0,98 atau 98 persen. Nilai ini berarti bahwa harga riil cabai rawit di pedagang besar dapat diterangkan oleh variabel bebasnya sebesar 98 persen yang dimasukkan dalam model, sedangkan sisanya 2 persen diterangkan oleh variabel-variabel lain yang tidak diteliti di dalam model.

\section{b. Uji F}

Uji F digunakan untuk mengetahui apakah variabel bebas secara bersamasama berpengaruh nyata terhadap variabel tak bebasnya pada tingkat signifikansi $(\alpha)$ tertentu. Berdasarkan Tabel 5.17 analisis varian harga cabai rawit pedagang kecil dengan pedagang besar didapatkan nilai $\mathrm{F}$ hitung sebesar 179,663 dengan tingkat signifikansi 0,000 . F hitung lebih besar dari $\mathrm{F}$ tabel, maka model regresi secara keseluruhan tepat digunakan pada tingkat kepercayaan 95 persen. Hasil ini mengindikasikan bahwa variabel bebas secara bersama-sama berpengaruh nyata terhadap variabel tidak bebas.

\section{c. Uji t}

Uji t merupakan uji yang digunakan untuk mengetahui apakah variabel bebas secara individu berpengaruh terhadap variabel tak bebasnya pada tingkat signifikansi $(\alpha)$ tertentu. Berdasarkan Tabel 5.17 dapat diketahui bahwa variabel bebas yang berpengaruh terhadap harga riil cabai rawit di pedagang kecil adalah selisih harga cabai rawit di pedagang besar antara bulan tertentu dengan bulan sebelumnya, harga cabai rawit di pedagang besar pada bulan sebelumnya. Sedangkan variabel yang tidak berpengaruh nyata adalah harga cabai rawit di pedagang kecil bulan sebelumnya.

Variabel selisih harga cabai rawit di pedagang besar antara bulan $t$ dengan bulan t-1 mempunyai nilai t hitung 0,343 yang nyata pada taraf kepercayaan 95 persen dengan nilai koefisien regresi 0,18 Tanda koefisien yang positif ini memberi petunjuk adanya hubungan searah antara selisih harga cabai rawit di pedagang besar antara bulan $t$ dengan bulan $\mathrm{t}-1$ dan harga cabai rawit di pedagang kecil pada 
bulan t. Berarti apabila ada peningkatan perubahan selisih harga di pedagang besar pada bulan $t$ dengan bulan $t-1$ sebesar satu satuan maka harga cabai rawit di pedagang kecil pada bulan $t$ akan naik sebesar 0,18 satuan.

Variabel harga cabai rawit di pedagang besar pada bulan t-1 mempunyai nilai t hitung 8,585 yang nyata pada taraf kepercayaan 95 persen dengan nilai koefisien regresi 0,494 . Tanda koefisien yang positif ini memberi petunjuk adanya hubungan searah antara harga cabai rawit di pedagang besar pada bulan t-1 dengan harga cabai rawit di pedagang kecil pada bulan $t$, berarti apabila ada peningkatan harga cabai rawit di pedagang besar pada bulan t-1 sebesar satu satuan maka harga cabai rawit di pedagang kecil pada bulan takan naik sebesar 0,494 satuan.

\section{d. Keterpaduan pasar antara pedagang besar dan pedagang kecil}

Perbandingan nilai koefisien regresi variabel harga cabai rawit di pedagang kecil pada bulan t-1 dengan nilai koefisien regresi variabel harga cabai rawit di pedagang besar pada bulan t-1 dapat diketahui nilai IMC sebesar 1,33. Menurut Timmer (1987) dalam Setyowati (2005), IMC dengan nilai kurang dari satu merefleksikan tingkat keterpaduan pasar dalam jangka pendek (short run integration) yang tinggi. Sedangkan apabila nilai IMC lebih besar dari satu merefleksikan tingkat keterpaduan pasar dalam jangka pendek (short run integration) yang rendah. Pada penelitian ini keterpaduan pasar antara pedagang kecil dengan pedagang besar memiliki keterpaduan pasar yang rendah yaitu dengan nilai IMC 1,33 atau lebih besar dari 1(Setyowati, Rahayu, \& Wahyuningsih, 2005). Artinya harga yang terjadi di pedagang besar sedikit yang ditransmisikan ke pedagang kecil. Dari perhitungan IMC dapat dijelaskan bahwa nilai koefesien harga di pedagang kecil pada waktu t-1 (a1) adalah 0,658. Sedangkan nilai koefesien harga di pedagang besar pada waktu t-1 (a3) adalah 0,494. Sehingga dapat dilihat bahwa hasilnya adalah 1,33. Semakin besar nilai IMC maka harga cabai rawit di pedagang kecil bulan sebelumnya tinggi dan harga cabai rawit di pedagang besar pada bulan sebelumnya rendah. Dan semakin rendah nilai IMC maka harga cabai rawit di pedagang kecil rendah dan harga cabai rawit pedagang besar pada bulan sebelumnya tinggi. Hal ini didukung oleh hasil uji $t$ yang menunjukkan bahwa variabel yang berpengaruh nyata terhadap harga di pedagang kecil adalah variabel harga di pedagang kecil bulan sebelumnya serta variabel selisih harga di pedagang besar bulan tertentu dengan bulan sebelumnya. Variabel harga di pedagang besar pada bulan sebelumnya tidak berpengaruh nyata terhadap harga di pedagang kecil

Hasil perhitungan skala likert yang digunakan sebagai pendukung analisis keterpaduan pasar menunjukkan bahwa rata rata secara keseluruhan tanggapan pedagang besar terhadap variabel harga di pedagang kecil bulan sebelumnya serta variabel selisih harga di pedagang besar bulan tertentu dengan bulan sebelumnya. Variabel harga di pedagang besar pada bulan sebelumnya tidak berpengaruh nyata terhadap harga di pedagang kecil ialah sedang. Hal ini menunjukkan bahwa pedagang besar kurang memperhatikan harga di pedagang kecil bulan sebelumnya serta selisih harga di pedagang besar bulan tertentu dengan bulan sebelumnya dan harga di pedagang besar pada bulan sebelumnya tidak berpengaruh nyata terhadap harga di pedagang kecil. 
Hasil kuisioner untuk pedagang kecil menunjukkan bahwa ada dua variabel yang sedang yang menunjukkan bahwa pedagang kecil kurang memperhatikan. yaitu variabel harga di pedagang kecil bulan sebelumnya serta variabel selisih harga di pedagang besar bulan tertentu dengan bulan sebelumnya. Dari hasil ini menjelaskan bahwa untuk sementara sikap kurang pedulian pedagang besar dan pedagang kecil terhadap perubahan harga baik di pedagang kecil bulan sebelumnya dan selisih harga pedagang besar bulan tertentu dan bulan sebelumnya menunjukkan bahwa hasil hitung IMC lebih besar dari satu yang menyebabkan keterpaduan pasar dalam jangka pendek rendah.

Hal yang dapat menyebabkan nilai IMC tinggi dan rendah yaitu IMC tinggi apabila harga cabai rawit di pedagang kecil pada bulan sebelumnya tinggi dan harga cabai rawit di pedagang besar pada bulan sebelumnya rendah. Dan nilai IMC rendah apabila harga cabai rawit di pedagang kecil pada bulan sebelumnya rendah dan harga cabai rawit di pedagang besar pada bulan sebelumnya tinggi.

Pengumpulan informasi tentang harga cabai di pedagang besar masih belum tersedia di data resmi Dinas Perdagangan dan Perindustrian Kabupaten Situbondo sehingga informasi pedagang pedagang kecil kurang, Sehingga pedagang kecil tidak mendapat cukup informasi tentang perubahan harga cabai. Data resmi hanya ada tiga pasar di Kabupaten Situbondo yang ada di Web Siskaberbapo yaitu Pasar Mimbaan Baru, Pasar Ardiejo dan Pasar Sumber Kolak. Di data tersebut lengkap mengenai harga harga cabai.

Pada penelitian antara pedagang kecil dan pedagan besar secara realita di lihat dari harga cabai rawit di pedagang besar maupun pedagang kecil secara garis besar bergerak searah, dimana apabila harga cabai rawit di pedagang besar naik maka di pedagang kecil juga akan naik dan apabila harga cabai rawit di pedagang besar turun makan di pedagang kecil turun. Akan tetapi jika dilihat dari hasil perhitungan yang menunjukkan bahwa nilai IMC rendah yang artinya keterpaduan pasar antar pedagang kecil dengan pedagang besar rendah. Hal ini diduga karena transmisi harga dari pedagang besar ke pedagang kecil kurang cepat, serta harga yang di informasikan oleh pedagang besar berubah setiap saat. Semakin besar jarak harga riil pedagang besar dan harga riil pedagang kecil maka kemungkinan tingkat keterpaduan pasarnya tinggi adalah rendah.

\section{KESIMPULAN}

Berdasarkan hasil penelitian dapat disimpulkan bahwa:

1. Besarnya nilai IMC antara pedagang kecil dan pedagang besar adalah 1,33 , artinya tingkat keterpaduan pasar cabai rawit dalam jangka pendek antara pedagang kecil dengan pedagang besar di Pasar Panji Kabupaten Situbondo rendah.

2. Hasil perhitungan kuisioner sedang yang menggambarkan sikap pedagang besar dan pedagang kecil terhadap harga cabai rawit pada bulan dasar dan bulan sebelumnya rendah,

\section{REFERENSI}

Dinas Tanaman Pangan, Holtikultura, dan Perkebunan Kabupaten Situbondo 2017. (n.d.). Data harga pasar tahun 2014-2017 di Kabupaten Situbondo. BPS Situbondo. 
Setyowati, S., Rahayu, W., \& Wahyuningsih, S. (2005). Analisis keterpaduan pasar komoditas wortel antara kota surakarta dan kabupaten karanganyar. SEPA: Jurnal Sosial Ekonomi Pertanian dan Agribisnis, 2(1). doi:10.20961/sepa.v2i1.48812

Simatupang, P. (2016). Pertumbuhan Ekonomi dan Nilai Tukar Barter Sektor Pertanian. Jurnal Agro Ekonomi, 11(1), 37-50. doi:10.21082/jae.v11n1.1992.37-50 